\title{
Approved Social Workers
}

\section{An Open Letter to the Secretary of State, Norman Fowler}

MIND is deeply unhappy about the turn of events in 'progress' towards the establishment of Approved Social Workers and has published the following open letter to the Secretary of State.

\section{Dear Mr Fowler}

The recent circular on interim directions for appointing Approved Social Workers is the result of a failure to reach agreement. We are now witnessing the consequence of lack of discussion with professional staff at the time that the Mental Health Act was being drafted.

The failure of all sides to agree to a workable formula within the spirit of the Act as intended by Parliament reflects badly on all parties. The Government should have made considerably more money available to local authorities to provide appropriate training for staff seeking to become Approved Social Workers, and encouragement should have been given to employers to develop better training programmes. The Central Council for Education and Training in Social Work (CCETSW) could have produced a less contentious assessment process incorporating a longer term training requirement-but to be fair to CCETSW they were given a very difficult task of assessing a large number of people in a relatively short time. The employers could have been more open to revaluing mental health social work and to encourage staff to undertake appropriate training; and NALGO could have been less intransigent over some of their demands. NALGO, however, have understandably been concerned at the creation of an 'élite', of the lack of negotiation during the run up to the legislation, and the problems about gradings of Approved Social Workers.

All of the above is and should be negotiable. What should never be negotiable is NALGO's insistence on 'blanketing-in' of existing Mental Welfare Officers as Approved Social Workers with no additional training or assessment requirements. Parliament quite clearly was demanding a new deal for mentally ill people, revaluation of mental health social work, and a new approach to a professional training in working with mentally ill people. To give in on the 'blanketing-in' issue would be to go against the wishes of Parliament and against informed opinion, which has become more and more concerned at the standards of mental health social work, a lack of training of those working with the mentally ill and the poor image and status of the social work profession.

The interim measures announced by yourself must be just that-a short-term solution to overcome the temporary difficulties of having sufficient accredited social workers at 28 October 1984. But that must not become an excuse to delay negotiations on the more fundamental issues which need agreement between the Government, employers, trade unions and CCETSW for a mutually acceptable way forward.

The purpose of this letter is to secure your assurance that you will: (a) reopen negotiations on additional government funding of training by local authorities for the ASW task; (b) take the lead with CCETSW on issuing national curriculum for local authorities on training; and (c) not, under any circumstances, accept 'blanketing-in' of existing staff as ASWs. I am concerned that some local authorities and NALGO branches may be interpreting your guidance as allowing local negotiation tantamount to 'blanketing-in'. It must be made clear that this is not the case.

At the end of the day this failure to agree means the only people losing out are mentally ill people; though social work and social workers will not get much out of it either! But the real reason for the changes brought by the Mental Health Act 1983 was to provide a better framework for social work with mentally ill people and particularly civil detention of those suffering from mental disorder. They are the people that matter and all efforts should be directed to their needs.

Yours sincerely

Christopher Heginbotham National Director, MIND

Notes: The Mental Health Act 1983 required local authorities to appoint Approved Social Workers to take on the responsibilities previously carried out by Mental Welfare Officers. Approved Social Workers would have appropriate training and experience in mental health. Local authorities, under the terms of the Mental Health Act. had a statutory obligation to appoint a sufficient number of ASWs to carry out the duties conferred by the Act. The CCETSW set an examination syllabus, but local authorities retained responsibility for instituting training programmes. Approved Social Workers' duties include: (i) applying for compulsory admission; (ii) interviewing patients in order to ensure that detention in hospital is appropriate; (iii) informing relatives of application for compulsory admission: and (iv) conveying patients to hospital after application for compulsory treatment is completed.

The implementation date for ASW arrangements was 30 October 1984 but NALGO's decision to boycott ASW exams has resulted in a shortage of social workers with approval status.

In September the DHSS issued a circular setting out transitional arrangements until the dispute over training is resolved. The circular makes provision for transitional approval of social workers who have not passed ASW exams where a council lacks sufficient ASWs to undertake its statutory duties under the Mental Health Act. Social workers approved in this transitional way should hold a CQSW or have been a warranted and experienced Mental Welfare Officer in post on $\mathbf{2 8}$ October 1982. Social workers should also have received appropriate training in carrying out ASW duties. No approval should be for a period exceeding five years. Further transitional approval arrangements include reappraisal by the employing authority of a social worker who changes jobs, regular review of appointments and adequate provision for refresher training. 